\title{
Bisphenol A-glycidyl methacrylate induces a broad spectrum of DNA damage in human lymphocytes
}

\author{
Kinga Drozdz • Daniel Wysokinski • \\ Renata Krupa $\cdot$ Katarzyna Wozniak
}

Received: 19 May 2010/ Accepted: 9 September 2010/Published online: 29 September 2010

(c) The Author(s) 2010. This article is published with open access at Springerlink.com

\begin{abstract}
Bisphenol A-glycidyl methacrylate (BisGMA) is monomer of dental filling composites, which can be released from these materials and cause adverse biologic effects in human cells. In the present work, we investigated genotoxic effect of BisGMA on human lymphocytes and human acute lymphoblastic leukemia cell line (CCRFCEM) cells. Our results indicate that BisGMA is genotoxic for human lymphocytes. The compound induced DNA damage evaluated by the alkaline, neutral, and $\mathrm{pH} 12.1$ version of the comet assay. This damage included oxidative modifications of the DNA bases, as checked by DNA repair enzymes EndoIII and Fpg, alkali-labile sites and DNA double-strand breaks. BisGMA induced DNA-strand breaks in the isolated plasmid. Lymphocytes incubated with BisGMA at $1 \mathrm{mM}$ were able to remove about $50 \%$ of DNA damage during 120-min repair incubation. The monomer at $1 \mathrm{mM}$ evoked a delay of the cell cycle in the $\mathrm{S}$ phase in CCRF-CEM cells. The experiment with spin trap-DMPO demonstrated that BisGMA induced reactive oxygen species, which were able to damage DNA. BisGMA is able to induce a broad spectrum of DNA damage including severe DNA double-strand breaks, which can be responsible for a delay of the cell cycle in the $S$ phase.
\end{abstract}

\footnotetext{
K. Drozdz · D. Wysokinski Department of Molecular Genetics,

University of Lodz, Lodz, Poland

R. Krupa $\cdot$ K. Wozniak $(\bowtie)$

Laboratory of DNA Repair, Department of Molecular Genetics,

University of Lodz, Lodz, Poland

e-mail: wozniak@biol.uni.lodz.pl
}

Keywords BisGMA - DNA damage - DNA repair . Reactive oxygen species $\cdot$ Cell cycle

\section{Introduction}

Dental filling composites are mixtures of materials that generally consist of an organic resin matrix, reinforcing inorganic filler and an agent that connects the filler and the resin matrix. The polymerizable matrix contains one or more base monomers such as bisphenol A-glycidyl methacrylate (BisGMA) and/or urethane dimethacrylate (UDMA), diluent co-monomers (2-hydroxyethylene methacrylate, HEMA; triethylene glycol dimethacrylate, TEGDMA) and various additives, like photoinitiators (e.g., camphoroquinone), co-initiators (e.g., dimethyl-aminobenzoic-acid-ester), inhibitor of polymerization (BHT) and photostabilizers (e.g., benzophenone).

Numerous studies indicate that various components may be released from composite restorations into the oral environment and may cause adverse local and systemic effects, like irritation to skin or eyes and gastrointestinal complaints (Mathias et al. 1979; Lonnroth and Shahnavaz 1997). In vitro studies revealed cytotoxic and genotoxic (Engelmann et al. 2004; Kleinsasser et al. 2004, 2006; Lee et al. 2006; Reichl et al. 2008; Poplawski et al. 2009, 2010; Pawlowska et al. 2010), mutagenic (Schweikl and Schmalz 1997; Arossi et al. 2010), estrogenic (Wada et al. 2004) and teratogenic (Schwengberg et al. 2005) effects of composite components. Dental composites may reach a millimolar concentration in the pulp, which can be high enough to be considered as potentially harmful for pulp cells and other cells in the human organism (Bouillaguet 2004). For example, HEMA leaching from dentin adhesives may reach concentrations as high as $1.5-8 \mathrm{mM}$ (Bouillaguet et al. 
Fig. 1 Structure of BisGMA<smiles>C=C(C)C(=O)OCC(O)COc1ccc(C(C)(C)c2ccc(OCC(O)COC(=O)C(=C)C)cc2)cc1</smiles>

1996). Similarly, the TEGDMA concentrations reaching the pulp could be around $4 \mathrm{mM}$ (Noda et al. 2002). The diffusion of monomers through the dentin is facilitated by the microchannels present in its structure. After diffusion through the dentin, the monomers may migrate further into the bloodstream.

Previously, it was observed that BisGMA (Fig. 1) showed relevant enhancement of DNA migration of lymphocytes in the comet assay starting at $10^{-4} \mathrm{M}$ with a maximum at $2.5 \times 10^{-2} \mathrm{M}$ (Kleinsasser et al. 2004). It demonstrated the highest DNA migration in comparison with HEMA, TEGDMA, and UDMA. It was also shown that BisGMA at the $\mathrm{EC}_{50}$ concentration of $0.09 \mathrm{mM}$ evoked the highest rate of DNA double-strand breaks formation in human gingival fibroblasts (HGF) (Urcan et al. 2010). In the present study, we investigated the genotoxic effect of BisGMA in human lymphocytes in detail. We employed the comet assay at three different pHs: $>13$ version revealing DNA single- and double-strand breaks as well as alkali labile sites, the $\mathrm{pH} 12.1$ version eliminating the expression of alkali labile sites and the $\mathrm{pH} 9$ version revealing only DNA double-strand breaks. In order to assess whether oxidative DNA damage may contribute to BisGMA-induced lesions, we employed two enzymes: endonuclease III (EndoIII) and formamidopyrimidineDNA glycosylase (Fpg). EndoIII converts oxidized pyrimidines into strand breaks, which can be detected by the comet assay (Collins et al. 1993). Fpg is a glycosylase initiating base excision repair in E. coli. It recognizes and removes 7,8-dihydro-8-oxoguanine (8-oxoguanine), the imidazole ring-opened purines 2,6-diamino-4-hydroxy5-formamidopyrimidine (Fapy-Gua) and 4,6-diamino5-formamido-pyrimidine (Fapy-Ade) as well as small amounts of 7,8-dihydro-8-oxoadenine (8-oxoadenine) (Krokan et al. 1997). The removing of specific modified bases from DNA by this enzyme leads to apurinic or apyrimidinic sites, which are subsequently cleaved by its AP-lyase activity giving a gap in the DNA strand, which can be detected by the comet assay (Evans et al. 1995). The kinetics of DNA damage repair was also measured. In order to evaluate the involvement of free radicals in the genotoxicity of BisGMA, we pre-treated the cells with nitrone spin trap-DMPO. Moreover, we checked the ability of BisGMA to DNA damage directly by using the plasmid relaxation assay. We used the cancer cells line-human acute lymphoblastic leukemia cell line (CCRF-CEM) to analysis of BisGMA-induced changes in the cell cycle.

\section{Materials and methods}

Chemicals

Bisphenol A-glycidyl methacrylate (BisGMA) (CAS number 1565-94-2), 5,5-dimethyl-1-pyrroline $N$-oxide (DMPO), low-melting-point (LMP) and normal-melting-point (NMP) agarose, phosphate-buffered saline (PBS), DAPI (4',6-diamidino-2-phenylindole), fetal bovine serum (FBS), penicillin, streptomycin and hydrogen peroxide were purchased from Sigma-Aldrich Co. (St. Louis, MO, USA). Plasmid DNA purification kit was provided by EURx (Gdansk, Poland). Cell viability and cell cycle kits were purchased in BD Bioscience (San Jose, CA, USA). All other chemicals were of the highest commercial grade available.

Cells

Lymphocytes were isolated from peripheral blood obtained from three, young (23-35 years), non-smoking men by centrifugation in a density gradient of Gradisol L (15 min, $280 \times g, 4^{\circ} \mathrm{C}$ ).

Human acute lymphoblastic leukemia cell line (CCRFCEM) cells were grown in RPMI 1640 medium supplemented with $10 \%$ FBS, $2 \mathrm{mM}$ L-glutamine, $100 \mathrm{IU} / \mathrm{ml}$ penicillin, and $100 \mu \mathrm{g} / \mathrm{ml}$ streptomycin in the presence of a $5 \% \mathrm{CO}_{2}$ atmosphere at $37^{\circ} \mathrm{C}$.

E. coli cells, strain DH5 $\alpha$ cells with pUC19 plasmid, were grown in a $\mathrm{LB}$ broth at $37^{\circ} \mathrm{C}$ overnight.

\section{Cell treatment}

BisGMA was taken from stock ethanolic solution $(1 \mathrm{M})$ and added to the suspension of the cells in RPMI 1640 medium to give final concentrations of $0.015,0.03,0.06$, $0.125,0.25,0.5$, and $1 \mathrm{mM}$. Lymphocytes were incubated with BisGMA for $1 \mathrm{~h}$ at $37^{\circ} \mathrm{C}$. The final concentration of ethanol in each sample was equal, i.e. $0.9 \%$. The control cells received the medium and ethanol at $0.9 \%$. Each experiment included a positive control, which was hydrogen peroxide at $20 \mu \mathrm{M}$ applied for $10 \mathrm{~min}$ at $4^{\circ} \mathrm{C}$. In spin trapping experiments, the incubation with BisGMA was preceded by addition of DMPO to a final concentration of $100 \mu \mathrm{M}$.

In the case of lymphocytes, each experiment was performed on the cells obtained from blood of three different donors. 
Cell viability

The BD Cell Viability Kit was used to determine the cell viability. The kit contains thiazole orange (TO) solution to stain all cells and propidium iodide (PI) to stain dead cells. Aliquots of $2 \mu \mathrm{l}$ of TO and $1 \mu \mathrm{l}$ of PI were added to $1 \mathrm{ml}$ of cell suspension containing $5 \times 10^{5}$ cells, producing the final staining concentrations of $84 \mathrm{nM}$ and $4.3 \mu \mathrm{M}$, respectively. The mixture was gently shaken and incubated for $5 \mathrm{~min}$ in room temperature to allow both dyes to enter the cells. The samples were acquired on a LSRII (BectonDickinson, San Jose, USA) flow cytometer equipped with $488 \mathrm{~nm}$ laser excitation and BD FACSDiva software v. 4.1.2. $5 \times 10^{5}$ cells were analyzed in each experiment repeated in triplicate.

\section{Comet assay}

The comet assay was performed under alkaline conditions essentially according to the procedure of Singh et al. (1988) with modifications (Collins et al. 1993; Evans et al. 1995) as described previously (Blasiak and Kowalik 2000). A freshly prepared suspension of the cells $\left(1-3 \times 10^{5}\right.$ cells $\left./ \mathrm{ml}\right)$ in $0.75 \%$ LMP agarose dissolved in PBS was spread onto microscope slides precoated with $0.5 \%$ NMP agarose. The cells were then lysed for $1 \mathrm{~h}$ at $4^{\circ} \mathrm{C}$ in a buffer consisting of $2.5 \mathrm{M} \mathrm{NaCl}, 100 \mathrm{mM}$ EDTA, $1 \%$ Triton X-100, $10 \mathrm{mM}$ Tris, $\mathrm{pH}$ 10. After the lysis, the slides were placed in an electrophoresis unit, DNA was allowed to unwind for $20 \mathrm{~min}$ in the solution consisting of $300 \mathrm{mM} \mathrm{NaOH}$ and $1 \mathrm{mM}$ EDTA, $\mathrm{pH}>13$. Electrophoresis was conducted in the electrophoretic solution containing $30 \mathrm{mM} \mathrm{NaOH}$ and 1 mM EDTA, $\mathrm{pH}>13$ at ambient temperature of $4^{\circ} \mathrm{C}$ (the temperature of the running buffer did not exceed $12^{\circ} \mathrm{C}$ ) for $20 \mathrm{~min}$ at an electric field strength of $0.73 \mathrm{~V} / \mathrm{cm}(28 \mathrm{~mA})$. The slides were then washed in water, drained, and stained with $2 \mu \mathrm{g} / \mathrm{ml}$ DAPI and covered with cover slips. To prevent additional DNA damage, all the steps described above were conducted under dimmed light or in the dark.

The assay at $\mathrm{pH} 12.1$ was performed essentially according to the same procedure as the alkaline version except the $\mathrm{pH}$ value. In the neutral version, electrophoresis was run in a buffer consisting of $100 \mathrm{mM}$ Tris and $300 \mathrm{mM}$ sodium acetate at $\mathrm{pH}$ adjusted to 9.0 by glacial acetic acid (Singh and Stephens 1997). Electrophoresis was conducted for $60 \mathrm{~min}$, after a 20-min equilibrium period, at $12 \mathrm{~V}$ $(100 \mathrm{~mA})$ at $4^{\circ} \mathrm{C}$.

The comets were observed at $200 \times$ magnification in an Eclipse fluorescence microscope (Nikon, Tokyo, Japan) attached to COHU 4910 video camera (Cohu, San Diego, CA, USA) equipped with a UV-1 filter block (an excitation filter of $359 \mathrm{~nm}$ and a barrier filter of $461 \mathrm{~nm}$ ) and connected to a personal computer-based image analysis system
Lucia-Comet v. 4.51 (Laboratory Imaging, Praha, Czech Republic). Fifty images were randomly selected from each sample.

The mean value of tail DNA (\%) in a particular sample was taken as an index of DNA damage in this sample and was used to display the results of all experiments.

\section{DNA repair}

To examine DNA repair by the comet assay, lymphocytes after treatment with BisGMA were washed and resuspended in a fresh, RPMI 1640 medium preheated to $37^{\circ} \mathrm{C}$. Aliquots of the cell suspension were taken immediately ("time zero") and at 30,60, and 120 min later. Placing the samples in an ice bath stopped DNA repair.

\section{Oxidative DNA damage}

The slides after cell lysis were washed three times ( $5 \mathrm{~min}$, $4^{\circ} \mathrm{C}$ ) in an enzyme buffer containing $40 \mathrm{mM}$ HEPES$\mathrm{KOH}, 0.1 \mathrm{M} \mathrm{KCl}, 0.5 \mathrm{mM}$ EDTA, and $0.2 \mathrm{mg} / \mathrm{ml}$ bovine serum albumin, $\mathrm{pH}$ 8.0. The slides were then drained. Aliquots of $30 \mu \mathrm{l}$ of EndoIII or Fpg at $1 \mu \mathrm{g} / \mathrm{ml}$ in the buffer were applied to the agarose on slides and incubation for $30 \mathrm{~min}$ at $37^{\circ} \mathrm{C}$ was performed (Collins et al. 1993; Evans et al. 1995). The slides were processed as describe above.

Cell cycle

The CycleTEST PLUS DNA Reagent Kit was used to determine the DNA index (DI) and cell cycle phase distributions. The method involved dissolving of the cell membrane lipids, eliminating the cell cytoskeleton with trypsin, digesting the cellular RNA and stabilizing the chromatin with spermine. Propidium iodine was bound to isolated nuclei, which were then run on the LSRII flow cytometer, emitting fluorescence in the range of $580-650 \mathrm{~nm}$ and equipped with a 585/42 filter to analyze the light emitting between 564 and $606 \mathrm{~nm}$ by the stained cells. The DI was obtained by dividing the mean of the relative content of the exposed G0/G1 population by the mean of the control G0/ G1 population.

In the cell cycle experiment, we used highly proliferating cells, human acute lymphoblastic leukemia cell line (CCRF-CEM) cells. Suspension of cells was washed three times in buffer solution, adjusted to the concentration of $10 \% \mathrm{ml}$ and then stained according to the manufacturer instruction. Results were analyzed by CellFIT software.

Plasmid relaxation assay

pUC19 plasmid were isolated from DH5 $\alpha$ E. coli cells with Genemtrix Plasmid Miniprep DNA Purification Kit (EURx, 
Gdansk, Poland) according to the manufacturer's instruction. The plasmid was exposed to $200 \mu \mathrm{M} \mathrm{H}_{2} \mathrm{O}_{2}$ and $20 \mu \mathrm{M}$ $\mathrm{FeCl}_{3}$ (Fenton reaction). We performed this reaction as a positive control to check the migration of the pUC19 plasmid multimeric forms (supercoiled (SC), open circular (OC) and linear (L)). Hydroxyl radical, which was generated in Fenton reaction, induced strand breaks in DNA and caused the relaxation of supercoiled plasmid. Structural differences between supercoiled, open circular, and linear forms of the plasmid accounted for their different electrophoretic mobility. Plasmid samples at $250 \mathrm{ng} / \mu \mathrm{l}$ were subjected to $1 \%$ agarose gel electrophoresis carried out in TAE (TrisAcetate-EDTA) buffer. The gel was stained with ethidium bromide $(0.5 \mu \mathrm{g} / \mathrm{ml})$, and the plasmid DNA was visualized under ultraviolet light $(302 \mathrm{~nm})$ and scanned by a CCD camera, and densitometry analysis was performed with the GeneTools by Syngene (Cambridge, UK) software.

\section{Data analysis}

The values of the comet assay in this study were expressed as mean \pm SEM from three experiments, i.e., data from three experiments were pooled and the statistical parameters were calculated. The data obtained from cell viability, cell cycle, and DNA damage in the plasmid as mean \pm SD. The differences between samples were evaluated by applying the Student's $t$ test.

\section{Results}

\section{Cell viability}

BisGMA evoked the significant decrease $(P<0.05)$ in the viability of lymphocytes only at maximal applied concentration equal to $1 \mathrm{mM}$ (Fig. 2).

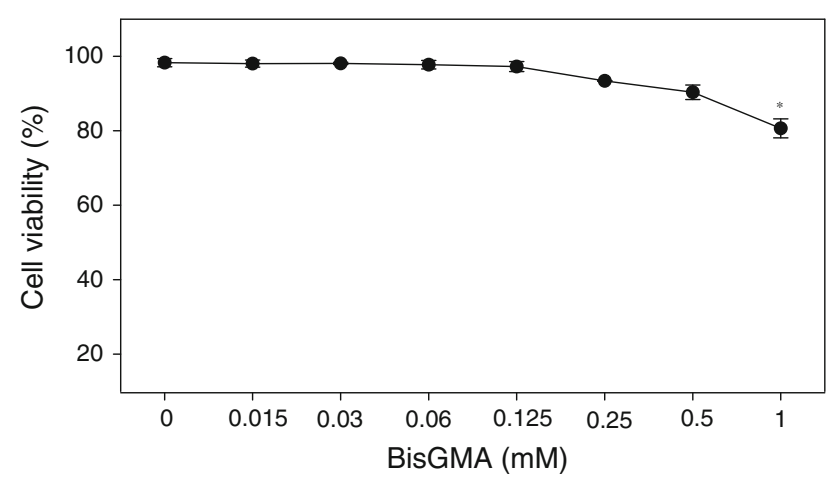

Fig. 2 Cell viability of human peripheral blood lymphocytes in the presence of BisGMA measured by flow cytometry with thiazole orange and propidium iodide. The figure shows mean results from three independent experiments. Error bars denote standard deviation; $* P<0.05$ when compared with the control $(0.9 \%$ ethanol)
DNA damage

The distributions of lymphocytes exposed to BisGMA according to their DNA damage (DNA in comet tail) measured in the alkaline version of the comet assay are displayed in Fig. 3. In the control, we observed the large fraction of comets, which had DNA damage between 0 and $5 \%$ and the small fraction of comets, which had DNA damage between 5 and $10 \%$. After incubation of the cells with increasing concentrations of BisGMA, we observed the increase of the comet fractions number with DNA damage. At maximal concentration of BisGMA, $1 \mathrm{mM}$, we noticed the most abundant fraction of the comets (40\%), which had DNA damage between 20 and 25\%. In lymphocytes exposed to hydrogen peroxide (positive control), the most abundant fraction $(40 \%)$ had DNA damage between 10 and $15 \%$.

Figure 4 displays DNA damage of lymphocytes exposed to BisGMA and analyzed by the comet assay in three versions of $\mathrm{pHs}:>13, \mathrm{pH} \mathrm{9}$, and $\mathrm{pH}$ 12.1. We observed significant differences between DNA damage at $\mathrm{pH}>13$ and $\mathrm{pH} 12.1$ versions $(P<0.001)$, which indicates that alkali-labile sites in DNA contributed to observed increase in DNA damage in the presence of BisGMA. We also observed significant increase at $\mathrm{pH} \mathrm{9,} \mathrm{which} \mathrm{indicates} \mathrm{that}$ DNA double-strand breaks also contributed to observed increase DNA damage after incubation with BisGMA. This experiment indicates that BisGMA can induce alkali-labile sites and double-strand breaks in DNA of human lymphocytes.

\section{Induction of oxidized bases}

Figure 5 shows DNA damage of lymphocytes exposed for $1 \mathrm{~h}$ at $37^{\circ} \mathrm{C}$ to BisGMA with post-treatment with EndoIII and Fpg. DNA originated from lymphocytes incubated at $0.015,0.125$, and $1 \mathrm{mM}$ BisGMA and treated with EndoIII and Fpg showed significant increase in DNA damage compared with DNA without treatment with BisGMA. This indicates that oxidative modifications of the DNA bases play a role in the genotoxic action of BisGMA.

\section{DNA repair}

Figure 6 shows DNA damage of lymphocytes exposed to BisGMA at 0.015 and $1 \mathrm{mM}$ immediately after exposure and 30, 60, and 120 min thereafter. Lymphocytes were not able to repair all BisGMA-induced DNA damage. After incubation with BisGMA at $0.015 \mathrm{mM}$, the cells were able to repair about $65 \%$ DNA damage. After incubation with BisGMA at maximal concentration, $1 \mathrm{mM}$, the cells were able to restore about $53 \%$ of DNA damage. 
Fig. 3 Histograms of the distribution of DNA damage in the comet alkaline version of lymphocytes incubated for $1 \mathrm{~h}$ at $37^{\circ} \mathrm{C}$ with BisGMA at various concentrations when compared with the control ( $0.9 \%$ ethanol). The results for positive control $\left(20 \mu \mathrm{M} \mathrm{H}_{2} \mathrm{O}_{2}\right.$ at $4^{\circ} \mathrm{C}$ for $10 \mathrm{~min}$ ) are also scored in each treatment was 50 . The figure shows mean results from three independent experiments presented. The number of cells

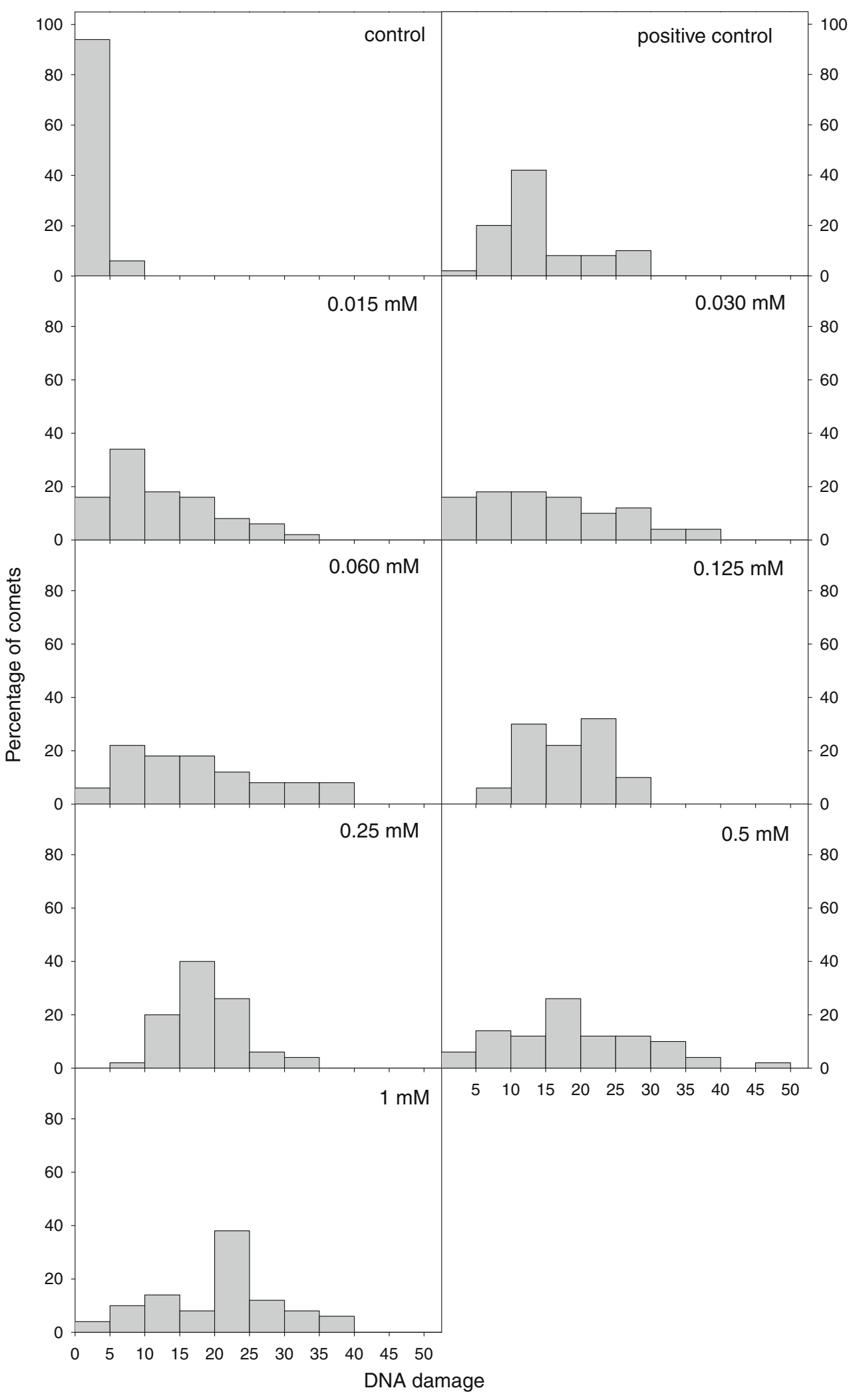

The cells exposed to $20 \mu \mathrm{M} \mathrm{H}_{2} \mathrm{O}_{2}$ for $10 \mathrm{~min}$ at $4^{\circ} \mathrm{C}$ (positive control) were able to repair about 57\% DNA damage within the repair incubation time of $120 \mathrm{~min}$ (Fig. 6).
Effect of spin traps on DNA damage

To check whether free radicals could contribute to observed DNA damage, we pre-incubated lymphocytes 


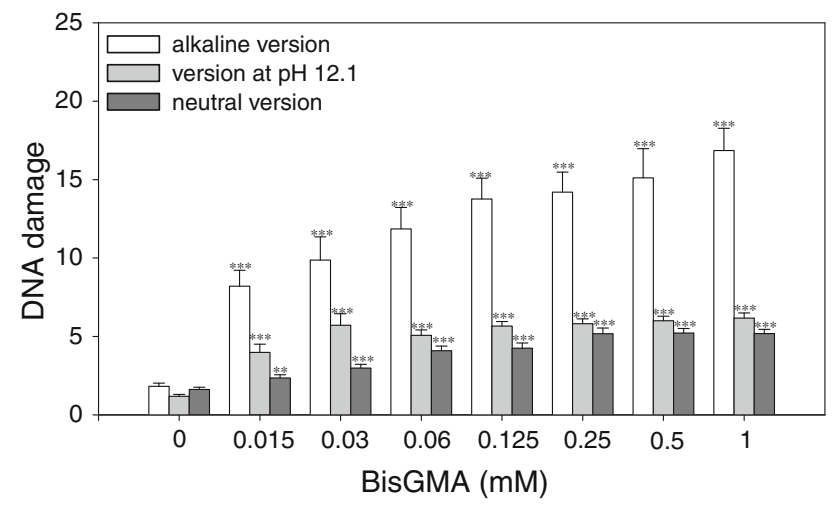

Fig. 4 DNA damage, measured as the comet tail DNA of lymphocytes incubated for $1 \mathrm{~h}$ at $37^{\circ} \mathrm{C}$ with BisGMA and analyzed by the comet assay in the alkaline (white), neutral (gray) or $\mathrm{pH} 12.1$ (black) version. The results for positive control were: at $\mathrm{pH}>13$ $16.19 \pm 2.08$; at $\mathrm{pH} 12.17 .59 \pm 1.10$, and at $\mathrm{pH} 96.05 \pm 0.53$. The number of cells scored in each treatment was 50 . The figure shows mean results from three independent experiments. Error bars denote SEM. The concentration axis is not linear and distances between points are chosen arbitrarily; $* * P<0.01 ; * * * P<0.001$ when compared with the control $(0.9 \%$ ethanol $)$

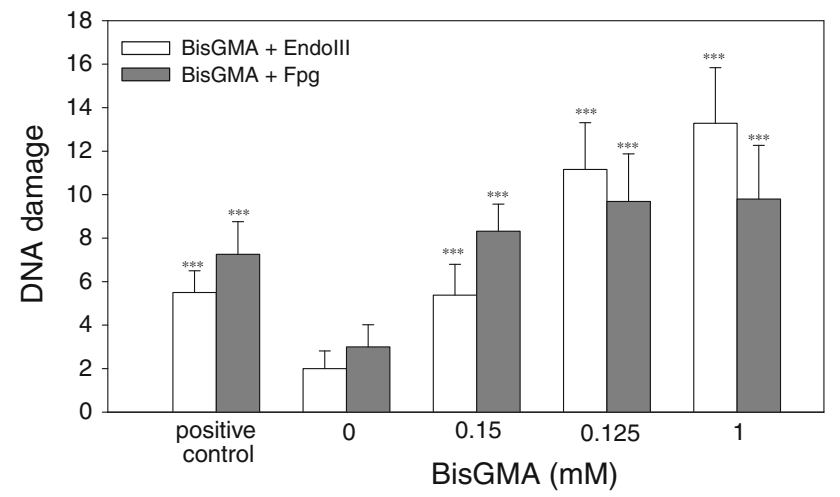

Fig. 5 DNA damage, measured as the comet tail DNA of lymphocytes incubated for $1 \mathrm{~h}$ at $37^{\circ} \mathrm{C}$ with BisGMA and treated with EndoIII (white) or Fpg (gray) at $1 \mu \mathrm{g} / \mathrm{ml}$. The value of comet tail DNA in the presence of either enzyme for all BisGMA concentrations was reduced by the value obtained in comet assay without any enzyme and the value for enzymatic buffer only. The number of cells scored in each treatment was 50 . The figure shows mean results from three independent experiments. Error bars denote SEM. The concentration axis is not linear and distances between points are chosen arbitrarily; $* * * P<0.001$

with spin trap DMPO. To check the ability of DMPO to scavenge reactive oxygen species (ROS) in our experimental conditions, incubation of lymphocytes with $\mathrm{H}_{2} \mathrm{O}_{2}$ at concentration of $20 \mu \mathrm{M}$ for $10 \mathrm{~min}$ at $4^{\circ} \mathrm{C}$ in the presence or in the absence of DMPO was performed. A significant decrease $(P<0.001)$ in DNA damage was observed after incubation of the cells with $\mathrm{H}_{2} \mathrm{O}_{2}$ (positive control) and DMPO in comparison with cells not treated with the trap $(18.02 \pm 1.31$ vs. $1.44 \pm 0.23)$. We observed a significant decrease $(P<0.001)$ in DNA damage induced by BisGMA

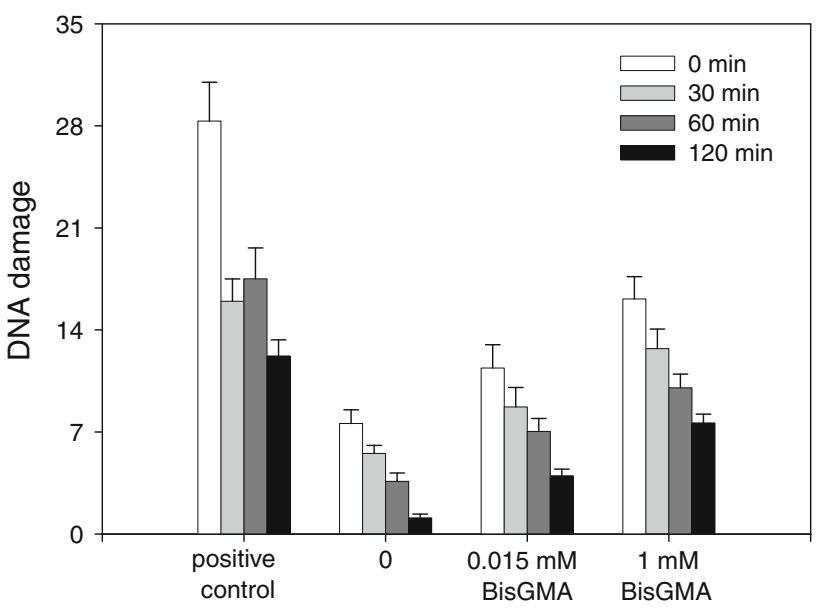

Fig. 6 Time course of the repair of DNA damage, measured as the comet tail DNA, in lymphocytes treated for $1 \mathrm{~h}$ at $37^{\circ} \mathrm{C}$ with BisGMA at 0.015 and $1 \mathrm{mM}$. The number of cells scored for each treatment was 50. The figure shows mean results from three independent experiments. Error bars denote SEM. The statistical significance is not indicated for the sake of clarity

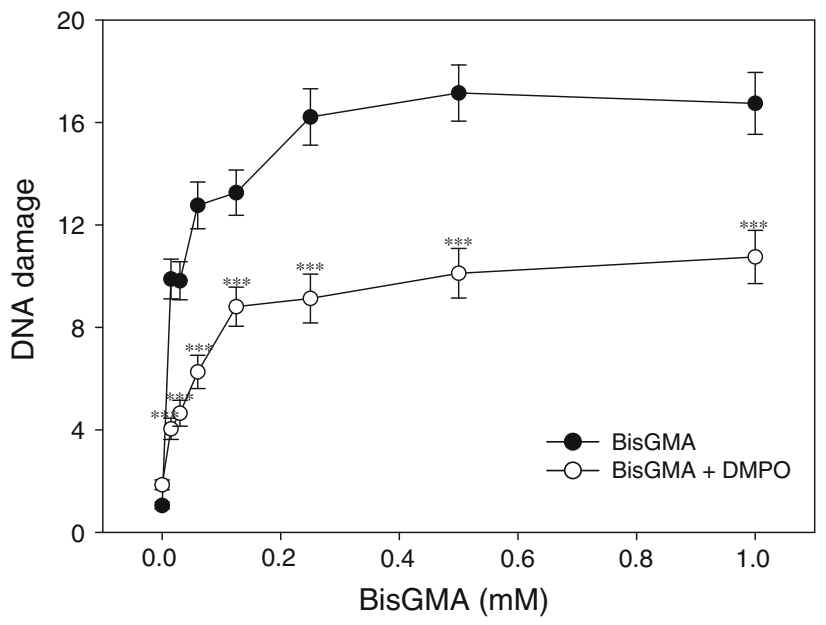

Fig. 7 DNA damage, measured as the comet tail DNA of lymphocytes incubated for $1 \mathrm{~h}$ at $37^{\circ} \mathrm{C}$ with BisGMA in the presence of DMPO at $100 \mu \mathrm{M}$. The number of analyzed cells in each treatment was 50. The figure shows mean results from three independent experiments. Error bars denote SEM; $* * * P<0.001$

in human lymphocytes in the presence of DMPO. This indicates that BisGMA induces ROS, which cause DNA damage (Fig. 7).

\section{Cell cycle}

In order to determine whether BisGMA has an influence on the progression of the cell cycle, human acute lymphoblastic leukemia cell line (CCRF-CEM) cells were exposed to BisGMA at increasing concentrations. BisGMA evoked 


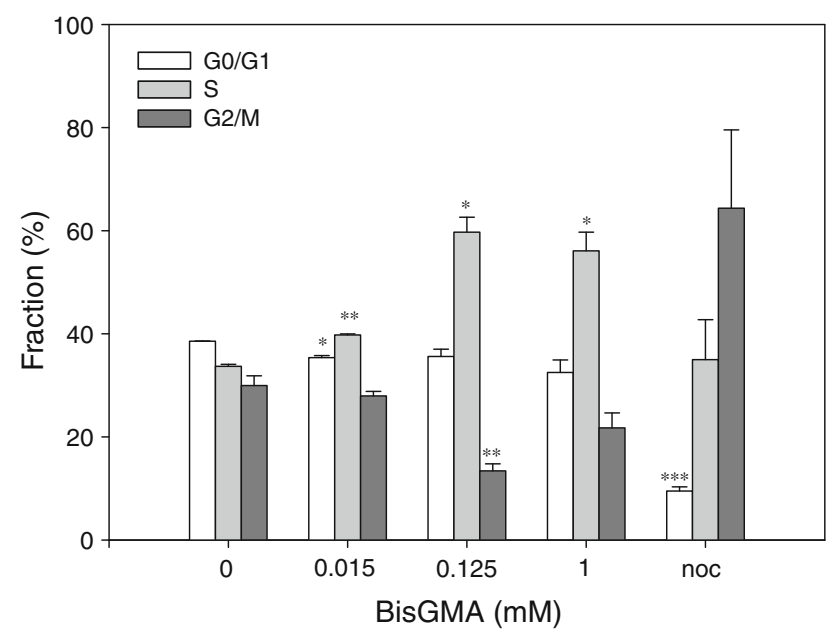

Fig. 8 Cell cycle analysis in CCRF-CEM cells exposed to BisGMA for $1 \mathrm{~h}$ at $37^{\circ} \mathrm{C}$. Percentage of cells in G0/G1 (white bars), S (light gray bars) and G2/M (dark gray bars) stage of cell cycle after treatment with BisGMA was presented. Nocodazole (noc) was used as a positive control. Data are expressed as means of three independent experiments, error bars denote $\mathrm{SD} ; * P<0.05 ; * * P<0.01$; $* * * P<0.001$

an increase in the $\mathrm{S}$ cell population accompanied by a decrease in G2/M cell population (Fig. 8).

\section{DNA damage in vitro}

BisGMA introduced DNA breaks to isolated DNA at the highest used concentration, as assessed by the plasmid relaxation assay (Fig. 9). The plasmid used in our experiment was sensitive to DNA-breaking agents as checked by Fenton reaction.

\section{Discussion}

Bisphenol A-glycidyl methacrylate (BisGMA) is used as to build the three-dimensional structure of the dental resin composites. The resin composites have been proposed as an alternative to amalgam, ceramic, and gold restorations due to esthetic and toxicologic considerations. However, numerous studies indicated that various components of the resin composites, like BisGMA, UDMA, and TEGDMA, may be released from composite into the oral environment and induced a variety of adverse biologic effects (Geurtsen 1998; Bouillaguet 2004). The release of monomers remains at a high level for a long time (7-28 days) after polymerization. A higher amount of BisGMA was eluted compared to TEGDMA. The $40 \mathrm{~s}$ that are usually used for the polymerization of resin composites seems insufficient in order to prevent a high release of monomers (Polydorou et al. 2007).

We showed that BisGMA is genotoxic for human lymphocytes. The compound induced mainly DNA alkali-labile sites and DNA double-strand breaks (Fig. 4). In our study, BisGMA was able to cause DNA-strand breaks in the isolated DNA plasmid (Fig. 9). This suggests that BisGMA can directly interact with DNA.

Reichl et al. (2008) showed that the addition of hydrogen peroxide $(0.06$ or $0.1 \mathrm{mM})$ resulted in a toxicity potentiation of TEGDMA and UDMA, but not of HEMA and BisGMA, on human gingival fibroblasts (HGF) and human pulp fibroblasts (HPF). Under physiologic conditions, the antioxidative enzymes catalase and glutathione peroxidase are able to maintain the concentration of hydrogen peroxide in cells on level of about $10^{-7} \mathrm{M}$. Otherwise damage of the antioxidative systems and/or increased oxidative stress can lead to dramatic endogenous increase of hydrogen peroxide in the cells and thereby can lead to cell damage (Reichl et al. 2008). It was shown that BisGMA at concentrations $>0.1 \mathrm{mM}$ caused an extreme depletion of the intracellular GSH pool as well as apoptosis in HGF (Engelmann et al. 2004). Moreover, it was found that BisGMA significantly influences the activity of cytochrome P450 (Cannon et al. 2000). An elevated activity of this mitochondrial enzyme complex may by associated with an increase of the intracellular concentration of ROS, which subsequently deplete the cells' pool of detoxifying glutathione (Engelmann et al. 2004; Sapone et al. 2003). We showed that lymphocytes exposed to BisGMA in the presence of spin trap, DMPO, had smaller DNA damage than the cells exposed without DMPO (Fig. 7). This finding indicates that BisGMA induces ROS, which damage DNA. We also speculate that oxidative modifications of DNA recognized by EndoIII and Fpg, which we noticed after incubation with BisGMA (Fig. 5), could be a result of ROS action.

Probably, the disruption of stable redox balance between ROS and antioxidant protective systems can be responsible for cell-cycle arrest induced by BisGMA (Fig. 8). BisGMA evoked an increase in the $S$ cell population accompanied by a decrease in G2/M cell population. DNA damage can block the progression of cell cycle giving more time for DNA repair. Schweikl et al. (2005) investigated the effect of TEGDMA on the cell cycle and showed that this compound caused cell cycle delays through p53-dependent and independent pathways in various mammalian cell lines, including pulp fibroblasts. $\mathrm{N}$-acetylcysteine protected mammalian cells from the cell cycle delay induced by TEGDMA and HEMA (Schweikl et al. 2007). Previously, it was shown that BisGMA evaluated to produce DNA damage but without cell-cycle effects, suggesting that DNA repair mechanisms were effective (Kostoryz et al. 2004). In our studies, the cells were able to restore about $53 \%$ of DNA damage after incubation with maximal, $1 \mathrm{mM}$ concentration of BisGMA (Fig. 6). This suggests that DNA damage may be persistent at about $50 \%$ and potentially dangerous for the cells. 
Fig. 9 DNA damage induced by BisGMA in the isolated pUC19 plasmid. The picture shows three forms of the plasmid: linear (L), open circular (OC) and super coiled (SC) exposed to BisGMA for $1 \mathrm{~h}$ at $37^{\circ} \mathrm{C}$ at indicated concentrations or Fenton reaction (positive control). The samples were separated on a $1 \%$ agarose gel, stained with ethidium bromide, and visualized in UV light

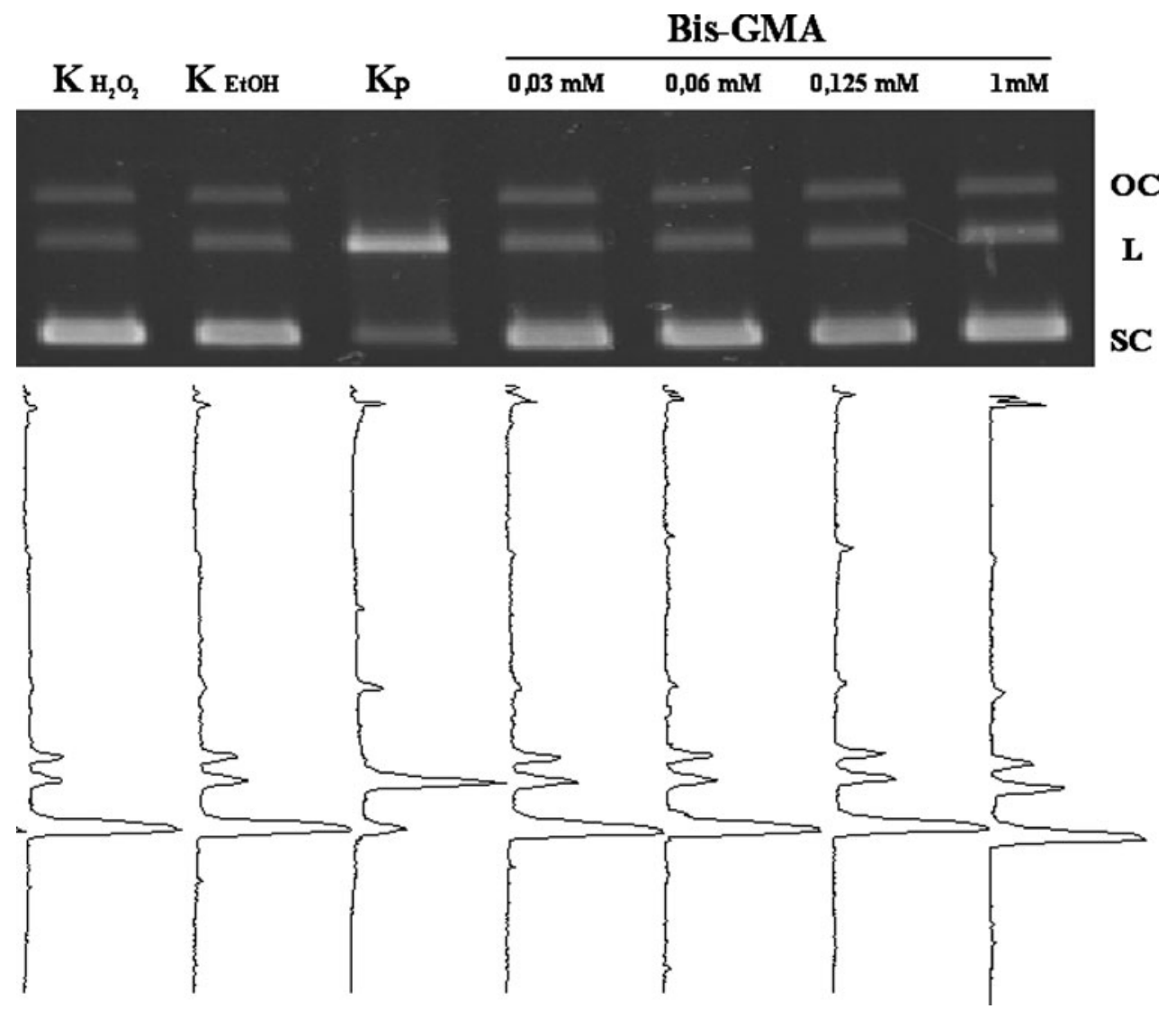

\section{Conclusion}

BisGMA is able to induce a broad spectrum of DNA damage including severe DNA double-strand breaks in human lymphocytes. The monomer can also directly interact with DNA and introduce DNA-strand breaks. BisGMA-induced DNA damage can be responsible for a delay of the cell cycle in the $\mathrm{S}$ phase.

Acknowledgments This work was supported by the grant NN 403 188134 of Ministry of Science and Higher Education. The authors thank Malgorzata Stanczyk for the gift of CCRF-CEM cell line and Dominika Ksiazek for her technical assistance.

Open Access This article is distributed under the terms of the Creative Commons Attribution Noncommercial License which permits any noncommercial use, distribution, and reproduction in any medium, provided the original author(s) and source are credited.

\section{References}

Arossi GA, Lehmann M, Dihl RR, Reguly ML, de Andrade HH (2010) Induced DNA damage by dental resin monomers in somatic cells. Basis Clin Pharmacol Toxicol 106:124-129

Blasiak J, Kowalik J (2000) A comparison of the in vitro genotoxicity of tri- and hexavalent chromium. Mutat Res 469:135-145
Bouillaguet S (2004) Biological risks of resin-based materials to the dentin-pulp complex. Crit Rev Oral Biol Med 15:47-60

Bouillaguet S, Wataha JC, Hanks CT, Ciucchi B, Holtz J (1996) In vitro cytotoxicity and dentin permeability of HEMA. J Endod 22:244-248

Cannon MJ, Kostoryz E, Russo KA, Smith RE, Yourtee DM (2000) Bisphenol A and its biomaterial monomer derivatives alteration of in vitro cytochrome P450 metabolism in rat, minipiug and human. Biomacromolecules 1:656-664

Collins AR, Duthie SJ, Dobson VL (1993) Direct enzymatic detection of endogenous base damage in human lymphocyte DNA. Carcinogenesis 14:1733-1735

Engelmann J, Janke V, Volk J, Leyhausen G, Von Neuhoff N, Schlegelberger B, Geurtsen W (2004) Effects of BisGMA on glutathione metabolism and apoptosis in human gingival fibroblasts in vitro. Biomaterials 25:4573-4580

Evans MD, Podmore ID, Daly GJ, Perrett D, Lunec J, Herbert KE (1995) Detection of purine lesions in cellular DNA using single cell gel electrophoresis with Fpg protein. Biochem Soc Trans 23:434S

Geurtsen W (1998) Substances released from dental composites and glass ionomer cement. Eur J Oral Sci 106:687-695

Kleinsasser NH, Wallner BC, Harreus UA, Kleinjung T, Folwaczny M, Hickel R, Kehe K, Reichl F-X (2004) Genotoxicity and cytotoxicity of dental materials in human lymphocytes as assessed by the single cell microgel electrophoresis (comet) assay. J Dent 32:229-234

Kleinsasser NH, Schmid K, Sassen AW, Harreus UA, Staudenmaier R, Folwaczny M, Glas J, Reichl F-X (2006) Cytotoxic and genotoxic effects of resin monomers in human salivary gland tissue and lymphocytes as assessed by the single cell microgel electrophoresis (Comet) assay. Biomaterials 27:1762-1770 
Kostoryz EL, Wetmore LA, Brockmann WG, Yourtee DM, Eick JD (2004) Genotoxicity assessment of oxirane-based dental monomers in mammalian cells. J Biomed Mater Res 68A:660-667

Krokan HE, Standal R, Slupphaug G (1997) DNA glycosylases in the base excision repair. Biochem J 325:1-16

Lee DH, Lim B-S, Lee Y-K, Ahn S-J, Yang H-C (2006) Involvement of oxidative stress in mutagenicity and apoptosis caused by dental resin monomers in cell cultures. Dent Mater 22:10861092

Lonnroth EC, Shahnavaz H (1997) Use of polymer materials in dental clinics, case study. Swed Dent J 21:149-159

Mathias CGT, Caldwell TM, Maibach HI (1979) Contact-dermatitis and gastro-intestinal symptoms from hydroxyethylmethacrylate. Br J Dermatol 100:447-449

Noda M, Wataha JC, Kaga M, Lockwood PE, Volkmann KR, Sano H (2002) Components of dentinal adhesives modulate heat shock protein 72 expression in heat-stressed THP-1 human monocytes at sublethal concentrations. J Dent Res 81:265-269

Pawlowska E, Poplawski T, Ksiazek D, Szczepanska J, Blasiak J (2010) Genotoxicity and cytotoxicity of 2-hydroxyethyl methacrylate. Mutat Res 696:122-129

Polydorou O, Trittler R, Hellwig E, Kummerer K (2007) Elution of monomers from two conventional dental composite materials. Dent Mater 23:1535-1541

Poplawski T, Pawlowska E, Wisniewska-Jarosinska M, Ksiazek D, Wozniak K, Szczepanska J, Blasiak J (2009) Cytotoxicity and genotoxicity of glycidyl methacrylate. Chem Biol Interact 180:69-78

Poplawski T, Loba K, Pawlowska E, Szczepanska J, Blasiak J (2010) Genotoxicity of urethane dimethacrylate, a tooth restoration component. Toxicol In Vitro 24:854-862

Reichl F-X, Seiss M, Marquardt W, Kleinsasser N, Schweikl H, Kehe $\mathrm{K}$, Hickel $\mathrm{R}$ (2008) Toxicity potentiation by $\mathrm{H}_{2} \mathrm{O}_{2}$ with components of dental restorative materials on human oral cells. Arch Toxicol 82:21-28

Sapone A, Affato A, Canistro D, Broccoli M, Trespidi S, Pozzetti L, Biagi CL, Cantelli-Forti G, Paolini M (2003) Induction and suppression of cytochrome P450 isoenzymes and generation of oxygen radicals by procymidone in liver, kidney and lung of CD1 mice. Mutat Res 527:67-80

Schweikl H, Schmalz G (1997) Glutaraldehyde-containing dentin bonding agents are mutagens in mammalian cells in vitro. J Biomed Mater Res 36:284-288

Schweikl H, Altmannberger I, Hanser N, Hiller KA, Bolay C, Brockhoff G, Spagnuolo G, Galler K, Schmalz G (2005) The effect of triethylene glycol dimethacrylate on the cell cycle of mammalian cells. Biomaterials 26:4111-4118

Schweikl H, Hartmann A, Hiller KA, Spagnuolo G, Bolay C, Brockhoff G, Schmalz G (2007) Inhibition of TEGDMA and HEMA-induced genotoxicity and cell cycle arrest by $\mathrm{N}$-acetylcysteine. Dent Mater 23:688-695

Schwengberg S, Bohlen H, Kleinsasser N, Kehe K, Seiss M, Walther UI, Hickel R, Reichl FX (2005) In vitro embryotoxicity assessment with dental restorative materials. J Dent 33:49-55

Singh NP, Stephens RE (1997) Microgel electrophoresis: sensitivity, mechanisms and DNA electrostretching. Mutat Res 383:167-175

Singh NP, McCoy T, Tice RR, Schneider EL (1988) A simple technique for quantitation of low levels of DNA damage in individual cells. Exp Cell Res 175:184-192

Urcan E, Scherthan H, Styllou M, Haertel U, Hickel R, Reichl F-X (2010) Induction of DNA double-strand breaks in primary gingival fibroblasts by exposure to dental resin composites. Biomaterials 31:2010-2014

Wada H, Tarumi H, Imazato S, Narimatsu M, Ebisu S (2004) In vitro estrogenicity of resin composites. J Dent Res 83:222-226 